I. type : high values of all 4 tests.

II. type : high values of B.M.R., P.B.I. and conversion ratio of $\mathrm{I}^{131}$ uptake.

III. type : elevated uptake of $\mathrm{I}^{131}$ with decreased B.M.R., P.B.I. and conversion ratio $\mathrm{I}^{131}$.

Finally, discussed the relation between the specificity of $\mathrm{I}^{181}$ uptake test and thyroid function.

\title{
Histochemical Studies upon the Experimental Diabetic and Sulfonylurea Administered Rabbits
}

By

\section{H. YOSHIDA, S. YOKOH, T. UEHIRA, M. IIZUKA and M. ISHIBASHI}

Glycogen and fat in main organs (liver, heart and kidney) of the experimental (alloxan, dithizone and oxine) diabetic and sulfonylurea administered rabbits are histochemically investigated. Demonstration of glycogen is performed by PAS staining method and fat is stained by Sudan black B.

A) Experimental diabetic rabbits ;

1) In the hypoglycemic stadium, i.e. 5-10 hours after injection of experimental diabetic agents, liver glycogen disappears at the periphery of liver acini.

2) In the initial period of the secondary hyperglycemic stadium (2-7 days after injection), decrease or disappearance of the liver glycogen are observed. Sometimes lipoid substances in the blood vessels of the liver and kidney are recognized in this period.

3) Glycogen in heart muscles shows increasing tendency throughout all stadiums in almost cases.

4) Glycogen degeneration at the epitherial cells of urinary tubules in the kidney and fat deposition in the liver and kidney are observed in the typical alloxanized rabbit inwhich hyperglycemia has continued several months.

B) Sulfonylurea administered rabbits ;

Liver glycogen decrease or disappear from the liver and blood sugar level increase about $25 \%$ higher than normal in the period of 15-60 minutes after oral administration of sulfonylurea. After then liver glycogen begin to increase and blood sugar level begin to decrease with the lapse of time, and after three hours liver glycogen reaches to the normal content, but hypoglycemia continue still more several hours.

\section{Histochemical Studies upon Vitamin $\mathrm{B}_{1}$ and $\mathrm{B}_{2}$ in the Experimental Diabetic and Sulfonylurea Administered Rabbits}

By

\section{H. YOSHIDA, S. YOKOH, T. UEHIRA and M. ISHIBASHI}

Vitamin $B_{1}$ and $B_{2}$ in main internal organs of the experimental diabetic and sulfonylurea administered rabbits are histochemically investigated. Vitamin $B_{1}$ is demonstrated as total vitamin $B_{1}$ by secondary fluorescence, and Vitamin $\mathrm{B}_{2}$ is visualized as free form by fluorescence. 
実験的糖尿家鬼及びスルファニール尿素剤投与家鬼に 於ける糖原及び脂肪の組織化学的検討

一特にスルファニール尿素羭の作用機序に関連して一

京都府立医科大学第一内科教室

吉田秀 雄, 横 尾 定 美, 上平富 男

飯塚道彦, 石橋睦夫

（本論交の要旨は第44回日本消化器病学会において発表した）

\begin{tabular}{|c|c|c|c|}
\hline & 目 & \multicolumn{2}{|l|}{ 次 } \\
\hline 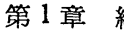 & $\overrightarrow{\overline{⿳ 亠 二 口}}$ & \multirow[t]{3}{*}{ 第 3 節 } & スルファニール尿素剂投与家鬼に \\
\hline 第 2 章 行 & 式 & & 扣ける臟器内糖原及び脂肪 \\
\hline 第 3 章 & 実験材料及び実験方法 & & （附）アロキサン及びスルファニール尿 \\
\hline 第 4 章 & 実験成績 & & 剂併用群 \\
\hline \multirow[t]{2}{*}{ 第 1 節 } & 正常家鬼に扣ける藏器内糖原及び & 第 5 章 総 & 忩括並びに考按 \\
\hline & 脂肪 & 第 6 章 結 & 吉 論 \\
\hline 第 2 節 & $\begin{array}{l}\text { 実験的糖尿家鬼に打ける臟器内糖 } \\
\text { 原及び脂肪 }\end{array}$ & & 献 \\
\hline
\end{tabular}

\section{第 1 章 緒言}

糖尿病においてはその物質代謝異常の結果, 種々の臟器に糖原変性, グルコース变性又は脂肪沈着を来す ことは既に剖検例及び実験的糖尿病について報告されているとてろであるが，私達は今回家鬼を用いて之を 追試し，併せて近時糖尿病治療剤として登場したスルファニール尿素剤投与家鬼の主要䁍器内糖原及び脂肪 の動龍を組織化学的に追究した.

第2章 術式

A) 組織化学的検查：糖原染色は小組織片を純アルコールにて固定，パラフイン包埋にてSchiff-PAS染色 を行い，併せて喠液反応を行つて糖原を確認した。 脂肪染色は10\%ホルモール固定，10〜15 凍結切片とし Sudan Black B 染色を行つた.

B）血糖測定は Hagedorn-Jensen 氏法によつた。

\section{第 3 章 実験材料及び実験方法}

\section{I ) 実験材料}

オカラ食に慣らした体重 $2 \mathrm{~kg}$ 前後の成熟家鬼を用い，対象臟器は心臟，肝臟及び腎臓とした。

II) 実験方法

A）実験的糖尿病

1）糖尿病発症方法 : 発症試薬としては Eastman-Codak 社製の Alloxan-Monohydrate を主として 用い，3 例に林純試薬社製の Dithizone 及び Oxine を用いた。 即ち Alloxan は $5 \%$ 水溶液として 150 $200 \mathrm{mg} / \mathrm{kg}$ を，Dithizone は予好 $70^{\circ} \mathrm{C}$ 亿温めた $0.2 \%$ アモニア液中に $1 \%$ の割で入れ， $70^{\circ} \mathrm{C} て ゙ 10$ 分間加温， 
溶解せしめ, 室温に放置, 冷却後滤過しその滤液を体重 Pro.kg 7 10cc 耳静脈注射を行つた. Oxine はそ の粉末を可及的少量の稀塩酸で溶解し，ついで蒸溜水で $1 \%$ 溶液となるように稀釈し, 体重 $1 \mathrm{~kg}$ 亿つ $6 \mathrm{cc}$ の割で耳静脈より注入した. 発症試薬投.与後数時間にして発現する低血糖ショック時には葡萄糖を $2 \sim 4 \mathrm{~g}$ 宛 $20 \%$ 水溶液として静注し，その後約 24 時間内に数回の同様ショックをみるもその度毎にほぼ同量の葡萄糖 を静注し総量 $10 \sim 20 \mathrm{~g}$ 程度注入した。

2) 観察方法

a) アロキサン糖尿家鬼(「ア家鬼)

i ）低血糖ショック期

ii）二次高血糖初期（アロキサン注入後 2７日迄を指す事とし，殆んど 全例において 48 時間目には $300 \mathrm{mg} / \mathrm{dl}$ 以上の高血糖を示し，7 日迄は少なくとも $150 〜 200 \mathrm{mg} / \mathrm{dl}$ 程度の高血糖を示した).

iii）二次高血糖後期（アロキサン静注後 8 日以後. 最む長期のあのは49日. 多くの例で漸次血糖の低下 を来し，屠殺当日は $130 〜 150 \mathrm{mg} / \mathrm{dl}$ に降下していた).

b) Dithizone 糖尿家鬼

c) Oxine 糖尿家鬼

b)，c）共試楽投与後 7 日目で屠殺.

B) スルファニール尿素㓮投与家鬼

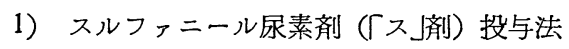

投与は全て経口的に行つた。即ち BZ 55 又は D 860 の所定量を約 $5 \mathrm{cc}$ の水性懸濁液として胃ゾンデを 用いて投与した．尚かかる操作のみによる血糖の変化を検討するために単に蒸溜水を投与して吟味した。

2) 観察方法

a)「ス」棛 1 回投与群

健常家鬼に BZ 55 を $0.25 \mathrm{~g} / \mathrm{kg}$ の割で早朝空腹時に投与，投与後 15 分，30分，45分，60分，90分及び 180 分迄追究.

b)「ス」剤連続投与群

健常家鬼に D 860 又は BZ 55 を 1 羽あたり $0.2 \mathrm{~g}$ 又は $0.5 \mathrm{~g}$ の割で連続 10〜16 日間投与，最終投与日の翌 日早朝に屠殺.

附：アロキサン又はヂチゾンとスルファニール尿素片併用家鬼

1）アロキサンヌはヂチゾン糖尿家躳の二次高血糖初期において a) BZ 55 を $0.25 \mathrm{~g} / \mathrm{kg} / \mathrm{Tag} 1$ 1 日 間投与，翌日屠殺。b) BZ 55 を $0.25 \mathrm{~g} / \mathrm{kg} 1$ 回投与後単時間の変化を追究したもの.

2）BZ 55 又は D 860 を $0.5 \mathrm{~g} / \mathrm{Kopf} / \mathrm{Tag} 10$ 日間投与後アロキサンを注射し，二次高血桾初期に屠殺 したあの.

以上についてむ 2,3 検討した.

第 4 章 実 験 成 績

\section{I ) 正常家鬼}

A) 糖 原

早朝空腹時における肝糖原は小葉 全域の肝細胞内に 小顆粒として 桷漫性に認められる。併し細胞内にお いては糖原顆粒は細胞筫の一側に偏して存在する事が多く，いずれの肝細胞も同側に顆粒を合む結果，丁度 屋根瓦を積み重ねた様な感を与える，乙れは染色法による人工的な結果である事は云うまであない，時によ つて小葉周辺部旰細胞に糖原の消失している事があり，全体として稍々減少している像がみられる，尚家白 においては肝糖原の減少している場合は常に必ず小葉周辺部細胞においてであつて，糖原が小葉中心部肝細 胞に認めらずに小葉周辺部細胞に認められるというととは如何なる場合にも観察されなかつた。 てれ即ち小 葉中心部䀒細胞が永久休止帯を言われる所以であろう. 又上述したように肝糖原の減少乃至消失は全肝細胞 
そわいて平均霄漫性に行われるあのでない事は，小葉周辺部肝細胞に全く糖原を認めない場合でも，小葉中 心部肝細胞に正常と全く变わらない多量の糖原を認めた事よりも充分窥われる。細胞核や星状細胞において は通常糖原は証明されないが，細胞に殆んど全く糖原を認めない旰細胞域に存在する星状細胞において，時 々糖原を認める場合もある。

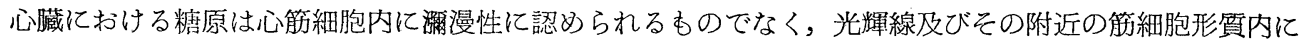
微細顆粒として多く認められる。その他の部位の細胞内には少量散在性に喼められるのみである. 尚糖原顆 粒の配列は横紋に一致して線状を成している。筋線維の横断面においては糖原は光輝線断面においては糖原 は光輝線の部分で斑状を成している。心筋全体としては心外膜に近い外側心筋群には殆んど認められず，内 側に行くに従い増加し乳頭筋に最も多い.

腎藏では婜乳頭部膸筫の集合管上皮細胞に相当多く認められる，多量に含まれる場合，個々の細胞につい ては肝細胞と略同程度に認められる。青山，門田1)の報告ではこの部分には認められないとしているが，私 達は睡液反応を施して消失することを見，糖原であることを確認した．その他主部の曲部，直部の上皮細胞

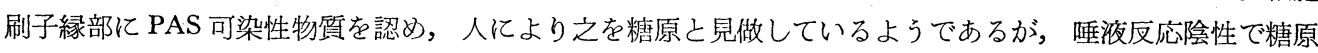
とは認められなかつた。

B) 脂 眆

心臓については検索しなかつた，肝蔵における脂肪の正常像は肝細胞の原形質内に微細脂肪滴之して認め られ，旰小葉の中心部，周辺部細胞の間には量的差違はない，核には認めない，星状細胞においては時に脂 肪の頜哴を胃る。伊東 ${ }^{20}$ の言う脂肪掑取細胞に該当するものであろうか. 腎においては細尿管上皮細胞に認 められるが特に潤䈏部，ヘンレー氏係蹄太部及び集合管の上皮細胞原形質内に肝細胞同様微細脂肪滴として 認められる。

\section{II) アロキサン糖尿家鬼}

\section{A) 糖 原}

i ）アロササン低血糖ショック期：旰では小葉周辺部肝細胞において糖原の消失を来すが，中心部細胞に は尚充分の糖原を認め，小葉全域に亘つて消失した例はなかつた．アロキサン毒のために小葉周辺細胞に変 性（細胞の膨潤，核のピクノーゼ等）を来した例（No. 131）ああつたが，斯る変性細胞においては糖原は 全く消失していた，心，筒における糖原には著変を認めなかつた。

ii）二次高血糖初期：乙の期においては肝糖原は減少乃至消失を来たす。その程度は肝小葉の略々外側半 分の肝細胞群に消失している程度のあのから，中心静脈を囲繞する最内側一㬝の畈細胞のみに認められるも の乃至は全く消失し去るあの等種々である. 殆んど又は全く消失した例においては星状細胞に糖原の認めら れる場合が多い，腎糖原に関しては著変なく，心においては稍増加している如く観察された，旰，腎，心共 核に糖原沈着を見たもの，糖原変性を認めたものは皆焣であつた。

iii）二次高血糖後期：䀒糖原は正常像を示すすのから減少乃至消失しているすの等種々であつた. 唯糖原 を含有する肝細胞においても個々の細胞を比較すると正常像程の均一性がなく，1個の細胞内における糖原 の存在性にあ不規則があるように見受けられた。尚 No. 83 は約 50 日間に亘り $300 \mathrm{mg} / \mathrm{dl}$ 以上の高血糖を持 続し，典型的なアロキサン糖尿を示した例であるが，糖原は小葉中心部(H)，周辺部(十)の程度に認めたが，

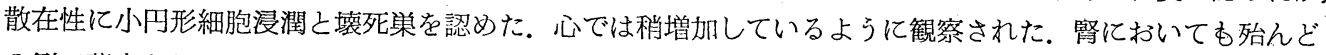
の例で著変を認めなかつたがNo.83において，正常像では糖原沈着の認められないヘンレ一氏係蹄太部に異 常な糖原沈着を認め，為に核の糖原変性をも来たしていた，同標本に唾液反応を施して糖原を消化，消失せ しめると該細胞は峰窩状を呈し核は一方に圧平され，細胞により核の存在を認めないあのがあつた。

\section{B) 脂 助}

アロキサン糖尿家鬼の各時期を総括して述べると，肝においては10日迄は著変をみないが， 2 週間前後以 上を経過すると稍増加しており脂肪榈む粗大化する。腎においては二次高血糖初期及び典型的「ア」家鬼 （No. 83）においてへンレ一氏係蹄太部，集合管の上皮細胞に稍増加を示し顆粒粗大となつた．後者の場合 
の所見は坂井 ${ }^{19)}$ の報告と一致する点である. 猶二次高血糖初期及び No. 83においては肝の小葉間動静脈, 中心静脈及び肝細胞索間の 毛細血管に，又繁では糸求 体係蹄及び他の血管内にも 脂肪の充填を認め顕著な脂 肪血症の像を呈していた。 肝，粲共脂肪変性や核の脂 肪沈着は認めなかつた。

「附」ヂチゾンオキシン 糖尿家兔

アロキサン糖尿家鬼に準 ずる成績を得た（第 1 表）

III) スルファニール尿素 㶡投与家鬼

a)「ス阂 1 回投与群

i ) 糖原 : 「ᄌ」剤投与 15 分 にして肝糖原は小葉周辺部 において減少又は消失し， 全体として中等度の減少を 示す. 次いで20分より60分 に亘り更に糖原は減少を来 たし，小葉中心部細胞群の みに残存する程度になる。

No. 241 では全く消失して いた，60分を過ぎると小葉 中心部より周辺部に向つて 除々に回復増加を来たし， 180 分にして略投与前の 像に復する。一方血糖值は 15分より60分に亘つて平均 して約 $25 \%$ 一時高血糖を 来す. 60 分を過ざると徐々 に下降を示し，正常值から 更に低血糖を来たす．心の 糖原は投与後15分にして既 に稍減少する如く見受けら れ，その減少は私達の観察 した 3 時間後迄持続してい る. 但し前述した如く，心 筋の糖原沈着は不規則で部 位的に差違が大で，斯る組 織化学的方法によりその多 第 1 表 正常家鬼並びに実験的糖尿家躳に扣ける藏器糖原の組織化学的分布

\begin{tabular}{|c|c|c|c|c|c|}
\hline \multirow{2}{*}{\multicolumn{2}{|c|}{ 家躳 No.（日数） }} & \multicolumn{2}{|c|}{ 肝 } & \multirow{2}{*}{$\begin{array}{c}\text { 腎 } \\
\text { (集 合 管) }\end{array}$} & \multirow{2}{*}{ (心 ${ }^{2}$ 心 } \\
\hline & & 肝 細 胞 & 星 細 胞 & & \\
\hline & & \multicolumn{2}{|c|}{ 正常家鬼（早朝空腹時） } & & \\
\hline \multicolumn{2}{|l|}{2} & (H) & $(-)$ & $(+)$ & $(+)$ \\
\hline \multicolumn{2}{|l|}{108} & $(H)$ & $(-)$ & $(-)$ & $( \pm)$ \\
\hline \multicolumn{2}{|l|}{136} & $(+1+)$ & $(-)$ & $(+)$ & $(H)$ \\
\hline \multicolumn{2}{|l|}{158} & (H) & $(-)$ & $(+)$ & $(+)$ \\
\hline \multicolumn{2}{|l|}{159} & $\left(H^{L}\right)$ & $(-)$ & $(-)$ & $(+) \sim(+)$ \\
\hline \multicolumn{2}{|l|}{160} & $(H !)$ & $(-)$ & $(H)$ & $(+)$ \\
\hline \multicolumn{2}{|l|}{162} & $(H)$ & $(-)$ & $(\mathrm{H})$ & $(+) \sim(+)$ \\
\hline & & \multicolumn{3}{|c|}{ アロキサン糖尿家鬼 (200mg/kg 静注) } & \\
\hline \multirow{2}{*}{\multicolumn{2}{|c|}{ 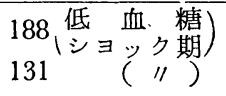 }} & $(H) \sim(H)$ & $(-)$ & $( \pm)$ & $( \pm)$ \\
\hline & & $(H)$ & $(-)$ & $(+)$ & $(H) \sim(H)$ \\
\hline 58 & $(11)$ & (HI) & $( \pm)$ & $(+)$ & $(+)$ \\
\hline 35 & (1 日) & $(H) \sim\left(H^{H}\right)$ & $(-)$ & $( \pm)$ & $(+) \sim(+)$ \\
\hline 98 & (2 日) & (HI) & $(-)$ & $(\perp)$ & $(H) \sim(H)$ \\
\hline 86 & (4 日) & $(-)$ & $(-)$ & $( \pm)$ & $( \pm)$ \\
\hline 90 & $(\prime \prime)$ & $\left(H^{1}\right)$ & $(-)$ & $( \pm)$ & $(+)$ \\
\hline 74 & $(" \prime)$ & $( \pm)$ & $( \pm)$ & $(-)$ & $(H)$ \\
\hline 209 & $(11)$ & $(-)$ & $(-)$ & $( \pm)$ & $(H) \sim(H)$ \\
\hline 119 & (5 日) & $(H)$ & $(-)$ & $(+)$ & $(H) \sim(H)$ \\
\hline 77 & $(\prime \prime)$ & $(H)$ & $(-)$ & $(-)$ & $(+)$ \\
\hline 2 & $(" 1)$ & $(H) \sim\left(H^{H}\right)$ & $(-)$ & $(+)$ & $(+) \sim(+)$ \\
\hline 6 & (6日) & $( \pm)$ & $(-)$ & $(+)$ & $(+)$ \\
\hline 7 & (7 日) & $( \pm)$ & $( \pm)$ & $(+)$ & $(+)$ \\
\hline 68 & $(\prime \prime)$ & (H) & $(-)$ & $( \pm)$ & $(+)$ \\
\hline 200 & $(\prime \prime)$ & $(H)$ & $(-)$ & $(+)$ & $(H)$ \\
\hline 65 & (14日） & $( \pm)$ & $( \pm)$ & ' & / \\
\hline 75 & (19日) & $( \pm)$ & $(-)$ & $(-)$ & $(+) \sim(+1)$ \\
\hline 8 & (20日) & (H) & $(-)$ & $(+)$ & $( \pm)$ \\
\hline 25 & $(11)$ & $(H)$ & $(-)$ & $(+)$ & $(+)$ \\
\hline 13 & $(\prime \prime)$ & $(-)$ & $( \pm)$ & $(+)$ & $(t+)$ \\
\hline 10 & (27日) & $(+)$ & $(-)$ & $(H)$ & $(+) \sim(+)$ \\
\hline 128 & (28日) & $(H) \sim\left(H^{+}\right)$ & $(-)$ & $(+)$ & $( \pm)$ \\
\hline 70 & (32日） & $( \pm)$ & $( \pm)$ & $(-)$ & $(+)$ \\
\hline 85 & (42日） & $( \pm)$ & $(+)$ & $(-)$ & $( \pm)$ \\
\hline 42 & （48日） & (m) & $(-)$ & $(-)$ & $(+)$ \\
\hline 83 & (49日） & $(H)$ & $( \pm)$ & $\mid \begin{array}{c}(H) \\
\text { ヘンレ一氏係 } \\
\text { 蹄糖原変性 }\end{array}$ & $(+)$ \\
\hline 79 & (50日) & $(+t) \sim(H)$ & $(-)$ & $(H)$ & $(H) \sim(H)$ \\
\hline
\end{tabular}

寡を論ずるととは至難であ 
り，私達の結諭も見た感 じにすぎない事を断つてお く。䴛糖原に関しては各時 間共著変を認め得なかつた (第 2 表).

ii）脂肪：肝，腎共正常 像と異つた点を認好かつ た。

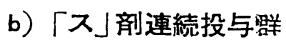

i ) 糖原：肝糖原江関し ては正常像を示すむのから 稍増加しているもの (No. 116，117), 減少している あの (No. 34, 109, 178) 等種々の像を呈し一定の傾 向を示さなかつた。心，腎 の糖原には著変はなかつた (第 3 表).

ii ) 脂肪 : 肝脂肪が僅加 に增加している例があつた が，腎においては変化を認 めなかつた。

「附」

アロキサン糖尿家鬼の二 次高血糖初期にスルファニ 一ル尿素郕 (BZ 55, 0.25g $/ \mathrm{kg} / \mathrm{Tag})$ を 1 ～ 2 日間投 与, 翌朝屠殺した群 : 肝糖 原は減少，心糖原は増加し ている如くに観察された。 腎糖原には著変を認めなか つた。即ち該時期のアロキ サン糖尿家鬼潐ずる結果 を得た，その他の実験に関 しては例数が少ないので成 績を表示するにとどめる。

ヂチゾン糖尿家鬼（80〜 $100 \mathrm{mg} / \mathrm{kg}$ 静注）

\begin{tabular}{|c|c|c|c|c|c|}
\hline 244 & (7日) & $( \pm)$ & $( \pm)$ & $(-)$ & \multirow{2}{*}{$\begin{array}{l}\left(H^{\prime}\right) \\
\left(H^{\prime}\right)\end{array}$} \\
\hline \multirow[t]{2}{*}{248} & $(\prime \prime)$ & $\left(H^{1}\right)$ & $(-)$ & $(H)$ & \\
\hline & & \multicolumn{3}{|c|}{ オキシン糖尿家鬼 $(60 \mathrm{mg} / \mathrm{kg}$ 静注 $)$} & \\
\hline 262 & (5日) & $(H)$ & $(-)$ & $(+)$ & $(+)$ \\
\hline
\end{tabular}

量的表現は 1 蔵器についての比較的のもので，他の藏器との間の比較に はならない，肝の册と心，留の州とは同程度を示すものでなく，心，腎 は肝に比し比較にならぬほどに少ない。

第 2 表 スルファニール尿素剤 1 回投与家兄に扔ける臟器糖原の組織化 学的分布 $-\mathrm{B} \mathrm{Z} 55,0.25 \mathrm{~g} / \mathrm{kg}-$

\begin{tabular}{|c|c|c|c|c|c|c|}
\hline \multirow{2}{*}{$\begin{array}{r}\text { 家鬼 } \\
\text { （時 }\end{array}$} & \multirow{2}{*}{$\begin{array}{l}\text { No. } \\
\text { 間） } \\
\end{array}$} & \multirow{2}{*}{$\begin{array}{l}\text { 血糖 }(\mathrm{mg} / \mathrm{dl}) \\
\text { 搵 } \\
\text { 揱 } \\
\text { 殺 前 }\end{array}$} & \multicolumn{2}{|c|}{ 肝 } & \multirow{2}{*}{$\begin{array}{c}\text { 腎 } \\
\text { (集合管) }\end{array}$} & \multirow{2}{*}{ (心 } \\
\hline & & & 肝 細 胞 & 星 細 胞 & & \\
\hline 231 & (15分) & $\begin{array}{r}71 \\
110 \\
\end{array}$ & (HH) & $( \pm)$ & $(+)$ & $(+)$ \\
\hline 240 & $(11)$ & $\begin{array}{l}85 \\
93 \\
\end{array}$ & $(H)$ & $(-)$ & (H) & $(+)$ \\
\hline 246 & (20分) & $\begin{array}{r}83 \\
102 \\
\end{array}$ & $(+)$ & $(-)$ & (H) & $( \pm)$ \\
\hline 247 & $(\prime \prime)$ & $\begin{array}{l}82 \\
91 \\
\end{array}$ & $(+)$ & $(-)$ & (H) & $(+)$ \\
\hline 221 & (30分) & $\begin{array}{r}83 \\
105\end{array}$ & $( \pm)$ & $(-)$ & $(+)$ & $(+)$ \\
\hline 232 & $(11)$ & $\begin{array}{l}63 \\
79 \\
\end{array}$ & (H) & $(+)$ & (H) & $(+)$ \\
\hline 230 & (45分) & $\frac{61}{-}$ & (H) & $(-)$ & $(+)$ & $(+)$ \\
\hline 229 & (60分） & 70 & $(+H)$ & $( \pm)$ & $(+)$ & $(+) \sim(+)$ \\
\hline 239 & $(11)$ & $\begin{array}{l}89 \\
80 \\
\end{array}$ & $(+)$ & $(-)$ & (H) & $(+)$ \\
\hline 241 & $(11)$ & $\begin{array}{r}79 \\
118 \\
\end{array}$ & $(-)$ & $(-)$ & $(+)$ & $(+)$ \\
\hline 245 & $(11)$ & $\begin{array}{l}92 \\
84 \\
\end{array}$ & $(+1+)$ & $(-)$ & $(+)$ & $(+)$ \\
\hline 242 & (90分） & $\begin{array}{lr} & 87 \\
40 \text { 分 } & 95 \\
60 \prime \prime & 100 \\
90 \prime \prime & 95 \\
\end{array}$ & (H) & $(+)$ & $(+)$ & $(t)$ \\
\hline 220 & (180分） & $\begin{array}{|rr|} & 87 \\
20 \text { 分 } & 105 \\
180 \text { ” } & 85 \\
\end{array}$ & (H) & $(-)$ & $(+)$ & $(+)$ \\
\hline
\end{tabular}

(第 4 表)，(第 5 表)，(第 6 表).

\section{第 5 章 総括並ひた考按}

\section{1) 実験的糖尿家鬼}

実験的糖尿病における糖原，脂肪に関する組織学的検索は既に多くの報告を見るとてろで私達はあくまで 追試にとどまつたが，二次高血糖初期において，即ち殆んどの例において $300 \mathrm{mg} / \mathrm{dl}$ 程度の高血糖を来た す時期において肝糖原の減少をみることは, 肝糖原動員による一過性現象と解し得るであろう。アロキサン注 射後 1 週を過ざると漸次血糖の低下をみるものが多かつた．乙の時期の肝糖原に関しては一定の傾向がな 
く，個々の例においては必 ずしむ血糖值之肝糖原量之 の間に逆双関の関係を見出 し得なかつた．乙の点は青 山，門田 ${ }^{1)}$ の報告と良く一 致する所で，血糖を左右す る因子が多岐に亘る点より 当然であろう。心筋内糖原 量に関しては前記青山, 門 田 ${ }^{1)}$ とると，アロキサン 糖尿家鬼では骨格筋に減少 するが心筋では却つて増加 する傾向にあると報告して いるが，我々の場合む同様 の結果を得た. 又種々の藏 器に糖原変性を来たし，脂 肪血症を起す事も岡本 ${ }^{1)}$ 及 びその協力者の報告にみる 所である。

II) スルファニール尿素 郕投与家鬼

「ス」剤投与による肝糖原 の態度については，その作 用機序之相俟つて種々の研 究成績が報告されている。 Loubatiers $^{2)}$, Tyberghein ${ }^{3)}$, Beringer U. Keibl ${ }^{4}$, Miller ${ }^{5}$ Lang $^{6}$ ， Bänder ${ }^{7}$ 等は「ス」 郕投与により肝糖原は増加 するとし，Galdonoff u. Suter ${ }^{8)}$ 等は減少するとして いるが, 私達の成績の如き, 「ス」剂投与後約 60 分迄は 減少し，次いで増加，回復 するという二相性を示す事 は，肝糖原に関しては未だ 報告をみない所である。唯 血糖の時間的測定の結果， 「ス」阂投与後一時的に血糖 上昇を来たす事は既に報告 をみる所であり (藤本 ${ }^{9)} そ$ の他）私達の場合も吉田 ${ }^{10)}$ により認められている。 こ
第 3 表 スルファニール尿素剂連続投与家鬼における藏器糖 原の組織化学的分布

\begin{tabular}{|c|c|c|c|c|c|}
\hline \multirow{2}{*}{$\begin{array}{c}\text { 家 鬼 } \\
\text { No. }\end{array}$} & \multirow{2}{*}{$\begin{array}{lll}\Gamma \text { ス」剂 } & \text { 種 } \\
\text { 投 } & \text { 与 } \\
\text { (投 与 } & \text { 量 } \\
\text { (投) }\end{array}$} & \multicolumn{2}{|c|}{ 肝 } & \multirow{2}{*}{$\begin{array}{c}\text { 腎 } \\
\text { (集合管) }\end{array}$} & \multirow{2}{*}{ （心 } \\
\hline & & 肝 細 胞 & 星 細 胞 & & \\
\hline 170 & $\begin{array}{c}\mathrm{D} 860 \\
0.2 \mathrm{~g} / \mathrm{Kopf} / \mathrm{Tag} \\
(16 \text { 日) }\end{array}$ & (m) & $(-)$ & (H) & $(H) \sim(H)$ \\
\hline 178 & $\begin{array}{c}\prime \prime \\
\text { (12日) }\end{array}$ & $(+)$ & $(+)$ & $(-)$ & $(+H) \sim(H)$ \\
\hline 179 & $\begin{array}{c}\prime \prime \\
\prime \prime \\
(10 \text { 日) }\end{array}$ & (II) & $(-)$ & $(+)$ & $(+) \sim(+)$ \\
\hline 180 & $\begin{array}{c}\prime \prime \\
\text { (16日) }\end{array}$ & $(+)$ & $(+)$ & $(+)$ & $(+) \sim\left(t^{+}\right)$ \\
\hline 152 & $\begin{array}{c}\text { 0.5g/Kopf/Tag } \\
(10 \text { 日) }\end{array}$ & $(+)$ & $( \pm)$ & $(H)$ & $(H)$ \\
\hline 34 & $\begin{array}{c}\text { B Z 55 } \\
0.5 \mathrm{~g} / \mathrm{Kopf} / \mathrm{Tag} \\
(10 \text { 日) }\end{array}$ & $(-)$ & $(-)$ & $(+)$ & $(+) \sim(+)$ \\
\hline 109 & $\begin{array}{l}\prime \prime \prime \\
(1 \prime \\
(1 \prime)\end{array}$ & $(+)$ & $(-)$ & $(-)$ & $(+) \sim(+)$ \\
\hline 116 & $\begin{array}{l}\prime \prime \prime \\
(\prime \prime)\end{array}$ & (H) & $(-)$ & $(H)$ & $(+)$ \\
\hline 117 & $\begin{array}{c}\prime \prime \\
\prime \prime \\
(14 日)\end{array}$ & $\left(H^{H}\right)$ & $(-)$ & (H) & $(+) \sim(+)$ \\
\hline
\end{tabular}

第 4 表 実験的桾尿発症前後に「ス」剂を投与した家鬼にお ける藏器糖原の組織化学的分布

\begin{tabular}{|c|c|c|c|c|c|}
\hline \multirow{2}{*}{$\begin{array}{l}\text { 家鬼 } \\
\text { No. }\end{array}$} & \multirow{2}{*}{ 条 } & \multicolumn{2}{|c|}{ 旰 } & \multirow{2}{*}{$\begin{array}{c}\text { 腎 } \\
\text { （集合管） }\end{array}$} & 心 \\
\hline & & 肝 細 胞 & 星 細 胞 & & （心 筋） \\
\hline 259 & $\begin{array}{l}\text { 「F゙」家秉第 } 2 \text { 病日に } \\
\mathrm{B} Z 55,0.25 / \mathrm{kg} \text { 投与 } \\
\text { 後15分 }\end{array}$ & $(+)$ & $(-)$ & $(H)$ & $( \pm)$ \\
\hline 265 & $\begin{array}{l}\Gamma F ゙ 」 \text { 家乘第 } 2 \text { 病日に } \\
\text { B Z } 55,0.25 \mathrm{~g} / \mathrm{kg} \text { 投 } \\
\text { 与後 } 100 \text { 分 }\end{array}$ & $(-)$ & $(-)$ & $(H)$ & $(H)$ \\
\hline 198 & $\begin{array}{l}\Gamma \mathcal{P} J \text { 家鬼第 } 5 \text { 病日に } \\
\text { B Z } 55,0.25 \mathrm{~g} / \mathrm{kg} \text { 投 } \\
\text { 与後 } 120 \text { 分 }\end{array}$ & $(+)$ & $(-)$ & (HI) & $(+14)$ \\
\hline 191 & $\begin{array}{l}\Gamma ア 」 \text { 家鬼第 } 2,3 \text { 病 } \\
\text { 日に B Z } 55,0.25 \mathrm{~g} / \\
\mathrm{kg} / \mathrm{Tag} \text { 投与, 翌朝 }\end{array}$ & $(-)$ & $( \pm)$ & $(-)$ & $(+)$ \\
\hline 193 & $\begin{array}{l}\Gamma ア 」 \text { 家兔第 } 3,4 \text { 病 } \\
\text { 日に B Z } 55 \text {. } 0.25 \mathrm{~g} / \\
\mathrm{kg} / \mathrm{Tag} \text { 投与, 翌朝 }\end{array}$ & $(+)$ & $( \pm)$ & $( \pm)$ & (HI) \\
\hline 183 & "I & $( \pm) \sim(+)$ & $(+)$ & $( \pm)$ & $(+)$ \\
\hline 195 & 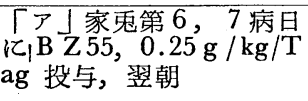 & $(+)$ & $(+)$ & $(+)$ & $(+)$ \\
\hline
\end{tabular}


の肝糖原の減少乃至消失は glycogenesis の障碍によ るあのでないととは「ス剤 投与前の肝糖原が充分保有 されていることより明かで

\begin{tabular}{|c|c|c|c|c|c|}
\hline 32 & $\begin{array}{l}\text { B Z } 55,0.5 \mathrm{~g} / / \mathrm{Kopf} / \\
\text { Tag 連続 } 10 \text { 日間投与後 } \\
\text { 「ア糖㽷発症, 第 } 6 \text { 病日 }\end{array}$ & $( \pm)$ & $( \pm)$ & $(+) \sim(+)$ & $(+)$ \\
\hline 41 & $\begin{array}{l}\mathrm{D} 860,0.5 \mathrm{~g} / \mathrm{Kopf} / \mathrm{Tag} \\
\text { 連続10日間投与後「ア」 } \\
\text { 糖尿発症，第 } 6 \text { 病日 }\end{array}$ & $(-)$ & $(+)$ & $(+)$ & $(H)$ \\
\hline
\end{tabular}
ある.よつて肝糖原の動員によるととは明白 であるが，乙の原因として，

i ) 釈ラ氏島 $\alpha$ 細胞刺戟による glucagon 分耖

ii）「ス」剤の肝に対する直接作用

iii) Adrenalin の分沁

等が考えられる.

i) に対しては V. Holt等1112) が I.P.T.D. の大量 $(1 \sim 2 \mathrm{~g} / \mathrm{kg})$ 投与により家鬼にお いて膵ラ氏島 $\alpha$ 細胞の変性をみたと報告して いるとと，井川131等が犬について，末梢静脈 に注射した場合に一過性血糖上昇作用をみな い程度の小量の「ス」剤即ち D860 の $0.05 \mathrm{~g}$ $/ \mathrm{kg}$ を A. pancreaticoduodenalis 亿注射す ると, 既に 5 分にして血糖上昇を来たし，次 いで低下する事を報告している。驿木谷 ${ }^{14)}$ 等 あラッテにBZ $55(1 \mathrm{~g} / \mathrm{kg})$ を腹腔内に注射 し 3 時間後に膵ラ氏島の変化を検索した結 果, $\alpha$ 細胞の顆粒配列に変化の起る事を報告 している. この木谷の研究は「ス」剤の作用機 序の 1 つと考えられる Antiglucagon 作用 を示唆する見解であるが，とのあのを更に押 し進めると「ス㓮投与の極く初期には「ス」 剂が $\alpha$ 細胞を刺㦸し, glucagon 分泌を高め る事屯考えられる．乙れ等の点より考えて $\alpha$ 細胞刺戟を否定する事は出来ない，然しなが ら私達はこの研究と平行して行つた脺ラ氏島 細胞の電子顕微鏡的観察において $\beta$ 細胞に著 変をみるに反し， $\boldsymbol{\alpha}$ 細胞には変化を見出し得 なかつた。 ii）に対する文献的根拠はないが， 私達の研究において 肝糖原の著明な変化を 来たすにあ拘らず， $\alpha$ 細胞に変化を認めなか

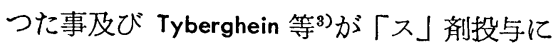
より肝糖原の増加を来たす事を認め，その機 転として glucose-6-phosphatase 活性の低下 を報告しているが，ての考えを更に押進めて 「ス闵投与の或る時期又はその濃度により該 酵素を刺㦸して, 肝糖原の動員を逆に促進せ

第 5 表 アロキサン糖尿家鬼及び「ス」剂投与家 鬼に扣ける肝，腎脂肪の組織化学的動態

\begin{tabular}{|c|c|c|c|}
\hline 家 鬼 & No. $\underset{\text { 件 }}{\text { 日 }}$ 数 & 肝 & 腎 \\
\hline 正常 & 家 鬼 & & \\
\hline 1 & & $(+)$ & $(H)$ \\
\hline 2 & & $(+t)$ & $(H)$ \\
\hline 3 & & $(H)$ & $(H)$ \\
\hline 235 & & $(H)$ & $(H)$ \\
\hline アロキサ & ンン糖尿家乘 & 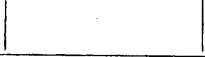 & \\
\hline 58 (低血 & 几糖ショック期） & $(H)$ & $(H)$ \\
\hline $188(11$ & ) & $(H)$ & (H) \\
\hline 35 & (1 日) & (H) & $(H)$ \\
\hline 98 & (2日) & $(H)$ & $(H)$ \\
\hline 74 & (4日) & $(H)$ & $(H)$ \\
\hline 78 & $(11)$ & $(H)$ & 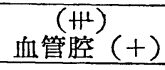 \\
\hline 86 & $(11)$ & $(+)$ & $(H)$ \\
\hline 90 & $(\prime \prime)$ & $(t) \sim(+)$ & $(H)$ \\
\hline 61 & (5日) & $\left|\begin{array}{c}(+1) \\
\text { 血管腔 }(+) \\
\text { 小葉中心部脂変 }\end{array}\right|$ & (\#) \\
\hline 77 & $(\prime \prime)$ & $(H)$ & $(\mathrm{H})$ \\
\hline 6 & (7日) & $(+)$ & $(H)$ \\
\hline 7 & $(11)$ & $(t+) \sim(H)$ & $(+1)$ \\
\hline 11 & (15日) & (HI) & $(H)$ \\
\hline 15 & $(\prime \prime)$ & (HII) & $(H)$ \\
\hline 75 & (19日) & $(+)$ & $(H)$ \\
\hline 8 & (20日) & $(H)$ & $(H)$ \\
\hline 13 & (20日) & 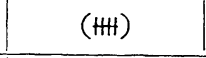 & $(H)$ \\
\hline 25 & $(\prime \prime)$ & (H) & - \\
\hline
\end{tabular}


しめる可能性が考えられる. 又上記井川等 ${ }^{13)}$ は前述の実験において同量を門脈に注射する と，一時的に血糖上昇を来たす事も同時に報 告している。併しての場合は A. pancreaticoduodenalis に注射した場合に比し，その 血糖上昇の発現が遅れ更に血糖上昇度も軽度 であるとしている事より，此は肝臟通過後大 環系に入り軴に至つて $\alpha$ 細胞を刺㦸する為の 2 次的作用と屯解し得る. iii) 亿対しては該 時期に果して血中 Adrenalin が増量している や否や目下検討中である。

「ス」剤投与後 60 分を経過すると血糖が低下 し，肝糖原は増加，回復を来たす事は本薬剤 の主効果であるが，私達の電子顕微鏡による 猝ラ氏島の観察では既に投与後 15 分にして $\beta$ 細胞に顆粒の減少乃至消失をみる。一方Gomori 氏 C.H.P. 染色によつても既に横尾 ${ }^{15)}$, 三宅 ${ }^{16)}$ 木谷 ${ }^{4)}$ 等がにより Hematoxylin 可染 性 $\beta$ 顆粒の诚少乃至消失を来たす事が報告さ れている. 電子顕微鏡像の $\beta$ 顆粒とGomori 氏染色による $\beta$ 顆粒とは全く同一物質である か否かは不明であるが，略同一の結果を示す あの之考え得る。 $\beta$ 顆粒の減少が直ち亿 $\beta$ 細 胞活性の亢進を示すすのとは結論出来ない し，反つて逆に抑制を示すすのとあ考光得る がいずれにしろ $\beta$ 細胞に何んらかの変化を来 たした事は明かである。乙の点が Loubatieres の $\beta$ 細胞刺㦸説に相当の支持を与えるものと

\begin{tabular}{|c|c|c|c|}
\hline 10 & (27日） & $(+1+)$ & (H) \\
\hline 42 & (46日) & $(+\#)$ & $(H)$ \\
\hline 83 & (49日) & 血管腔 $(+)$ & $\begin{array}{l}\text { (H+) } \\
\text { 血管腔 }(+)\end{array}$ \\
\hline \multicolumn{4}{|c|}{ 「ス」剂 1 回投与家鬼 } \\
\hline 231 & (15分) & $(H)$ & (H) \\
\hline 246 & (20分） & (H) & (H) \\
\hline 221 & (30分) & $(H)$ & $(H)$ \\
\hline 232 & $(" \prime)$ & $(H)$ & $(H)$ \\
\hline 230 & (45分) & $(H)$ & 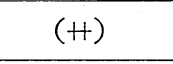 \\
\hline 241 & (60分） & $(H)$ & $(H)$ \\
\hline 220 & (180分） & \begin{tabular}{|c|} 
( $\left.{ }^{+}{ }^{L}\right)$ \\
小葉周辺部脂変
\end{tabular} & $(H)$ \\
\hline \multicolumn{4}{|c|}{ 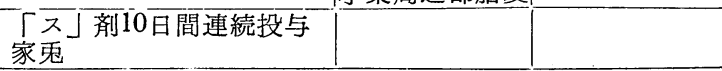 } \\
\hline & $\begin{array}{c}\text { B Z } 25 \\
0.5 \mathrm{~g} / \mathrm{Kopf} / \mathrm{Tag} \\
\end{array}$ & (H) & $(H)$ \\
\hline 109 & $"$ & (H) & $(H)$ \\
\hline 116 & "I & $(H)$ & $(H)$ \\
\hline & $\begin{array}{c}\mathrm{D} 860 \\
0.2 \mathrm{~g} / \mathrm{Kopf} / \mathrm{Tag}\end{array}$ & (II) & $(+H)$ \\
\hline 179 & $\begin{array}{c}\text { D860 } \\
0.5 \mathrm{~g} / \mathrm{Kopf} / \mathrm{Tag} \\
\end{array}$ & $(H)$ & (H) \\
\hline \multicolumn{4}{|c|}{$\begin{array}{l}\text { 事前「ス」剤投与アロキ } \\
\text { サン家鬼 }\end{array}$} \\
\hline & $\begin{array}{l}\text { B Z 55, Kopf/Tag } \\
\text { 10日聞投与後 「P」 } \\
\text { 糖尿発症, 第 } 6 \text { 病旦 }\end{array}$ & (H) & (H) \\
\hline 41 & " & (H) & (H) \\
\hline
\end{tabular}
考元られる。一方大橋 ${ }^{17}$ は組織像之低血糖期 との時間的ずれよりして，組織像はあくまで 組織像として受取るべきだとしている，又木谷 ${ }^{14)}$ ，乾等 ${ }^{19}$ あ同様な見解をとつているようである。翻つて 「ス」率が $\beta$ 細胞を刺㦸して Insulin を放出せしめるとしてあ直ちにてれのみが「ス」剤作用機転の凡てであ ると結論するわけには行かないだろう。併し協同研究者の一人吉田 ${ }^{100}$ はインシュリン測定の研究成績をも綜 合して，「ス凮投与後の一過性過血糖は一時的 $\alpha$ 細胞刺戟による glucagon 放出によるとし，その後の低 血糖は $\beta$ 細胞刺战による Insulin 分泌の結果であると結論している.

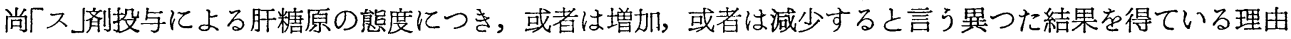
としては，私達の成績より見て，観察の時間的ずれが大きく左右していると考えられる。「ス剤に限らず或 薬剤投与により，或結果を生ずる条件としては，a）同一系薬剤でもその各誘導体により効果に多少の差違 が佮えられる， b ) 薬剤の働く場における一的時的血中濃度：これは投与方法（経口，注射），投与量によ つて決るものであるが，経口的投与の場合は更に誘導体の種頪の違いからくる胃，腸における易溶性，财収 性の問題がからむ， c) 働く場における血中濃度の持続性：投与量，排泄速度により決る。d) 被作働場 （個体藏恐）のその時の状態：例えばての場合肝糖原が充分䝪藏されていたや否や，d) 観察時間等が挙げ られる，乙れらの点は今更と>に述べる迄むないが，往々忘れ勝ちで，一定条件下の成績を以て全てを律し 
610 実験的糖尿家兔及びスルファニール尿素剂投与家鬼に於ける糖原及び脂肪の組織化学的検討 （吉田・他 4 名）

第 6 表 実験的糖尿家鬼及び「ス」剤投与家鬼に打ける藏器桾原並びに脂肪の組 織化学的変動——総括表一

\begin{tabular}{|c|c|c|c|c|c|}
\hline & \multicolumn{2}{|l|}{ 糖 } & 原 & \multirow{2}{*}{ 脂 } & \multirow{2}{*}{$\frac{\text { 肪 }}{\text { 霄 }}$} \\
\hline & 肝 & 腎 & 心 & & \\
\hline \multicolumn{6}{|c|}{ 正 常 家 鬼（対照） } \\
\hline 早 朝 空 腹 時 & $\mid \begin{array}{l}\text { 肝細胞内に籋漫 } \\
\text { 性に認める. 時 } \\
\text { 亿小葉周辺部肝 } \\
\text { 細胞群に少ない } \\
\text { 事あり }\end{array}$ & 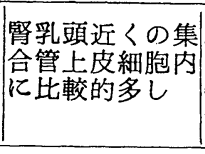 & 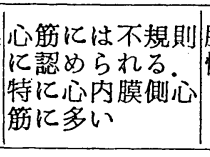 & $\mid \begin{array}{l}\text { 肝細胞内に漂慢 } \\
\text { 性に認める }\end{array}$ & $\begin{array}{l}\text { 細尿管上皮細胞 } \\
\text { 内に認む }\end{array}$ \\
\hline \multicolumn{6}{|c|}{ アロキサン糖尿家鬼 $\quad(200 \mathrm{mg} / \mathrm{kg}$ 静注） } \\
\hline 1）低血糖ショック期 & $\left|\begin{array}{l}\text { 小葉周辺部肝細 } \\
\text { 胞に減少 }\end{array}\right|$ & 著変なし & 著変なし & 著変なし & 著変なし \\
\hline $\begin{array}{l}2) \text { 二次高血糖 初期 } \\
(2 \sim 7 \text { 年 }\end{array}$ & 減少～消失 & 著変なし & \multirow{3}{*}{ 増加傾向 } & $\begin{array}{l}\text { 著変なし } \\
\text { 血管腔 }(+)\end{array}$ & $\begin{array}{l}\text { 稍壃加 } \\
\text { 血管腔 }(+)\end{array}$ \\
\hline $\begin{array}{l}\text { 二次高血糖後期 } \\
(8 \text { 50日) } \\
\text { (血糖低下するも } \\
\text { の多し) } \\
\end{array}$ & 正常～減少 & 著変なし & & 増加傾向 & 著変なし \\
\hline $\begin{array}{l}49 \text { 日間に亘り高 } \\
\text { 血糖 ( } 300 \mathrm{mg} / \\
\mathrm{dl}) \text { 持続例 }\end{array}$ & 稍 減 少 & $\mid \begin{array}{l}\text { 集合管著変なし } \\
\text { 记レ一係蹄 } \\
\text { 太部に糖原変性 } \\
\text { 核糖原変性 }\end{array}$ & & $\begin{array}{l}\text { 著変なし } \\
\text { 血管腔 }(+)\end{array}$ & $\begin{array}{l}\text { 稍増加 } \\
\text { 血管腔 }(+)\end{array}$ \\
\hline \multicolumn{6}{|c|}{ ヂチゾン及びオキシン糖尿家鬼 $(80 〜 100 \mathrm{mg} / \mathrm{kg}$ 及び $60 \mathrm{mg} / \mathrm{kg}$ 静注) } \\
\hline 二次高血 糖 初 期 & \multicolumn{3}{|c|}{ アロキサンに準ず } & - & - \\
\hline \multicolumn{6}{|c|}{ 「ス」剤 1 回投与家鬼（B Z 55, $0.25 \mathrm{~g} / \mathrm{kg}$ ) } \\
\hline 1） 15 分～20分 & 中等度減少 & 著変なし & \multirow{3}{*}{ 稍 減 少 } & \multirow{3}{*}{ 著変なし } & \multirow{3}{*}{ 著変なし } \\
\hline 2） 20 分～60分 & 減一著減一消失 & 著変なし & & & \\
\hline 3） 60 分〜180分 & 復 & 著変なし & & & \\
\hline \multicolumn{6}{|c|}{ 「ス」剤連続投与家鬼（D860～B Z 55，0.2 0.5 g / Kopf/Tag） } \\
\hline 最終投与日 翌 朝 & 増加, 正常, 減少| & 著変なし & 著変なし & $\begin{array}{l}\text { 稍増加する } \\
\text { 例あり }\end{array}$ & 著変なし \\
\hline
\end{tabular}

ようとする為に，全く逆の結果を得るに至るのではなからうか。

\section{第6 章 結 論}

1）肝糖原の動員は如何なる場合においても（細胞変性を来たす揚合は除く）常に小葉周辺部細胞から行 われ，全細胞に平均涌漫性に行はれるものではない。

2）実験的糖尿病

i ) 二次高血糖初期においては肝糖原は減少乃消失する.

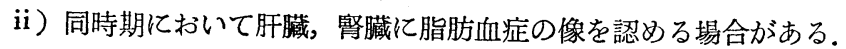


吉田・横尾 ·上平 ·飯塚・石橋論文附図（其の I )

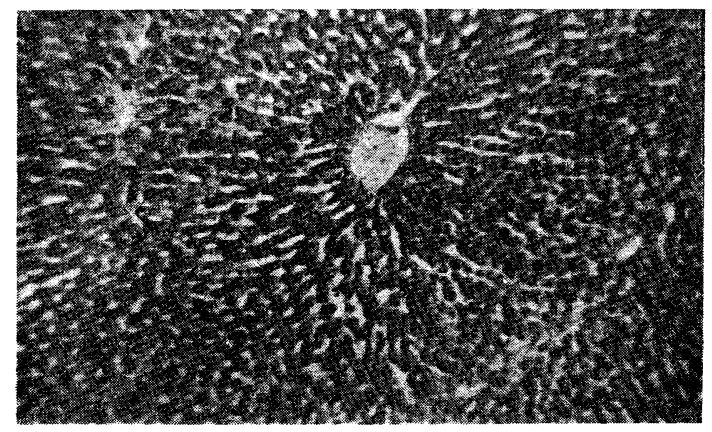

第 1 図

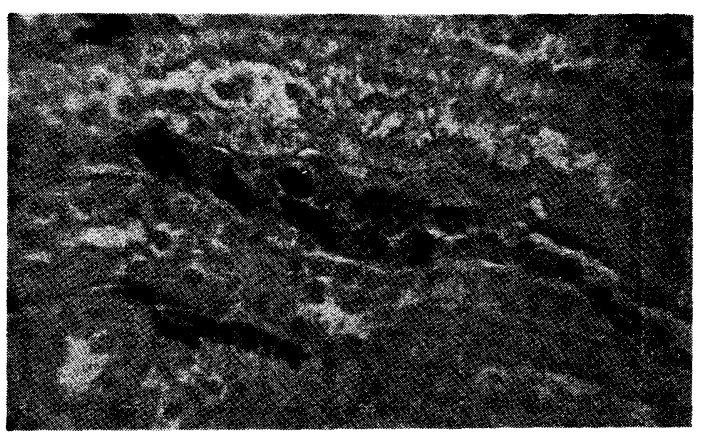

第 3 図

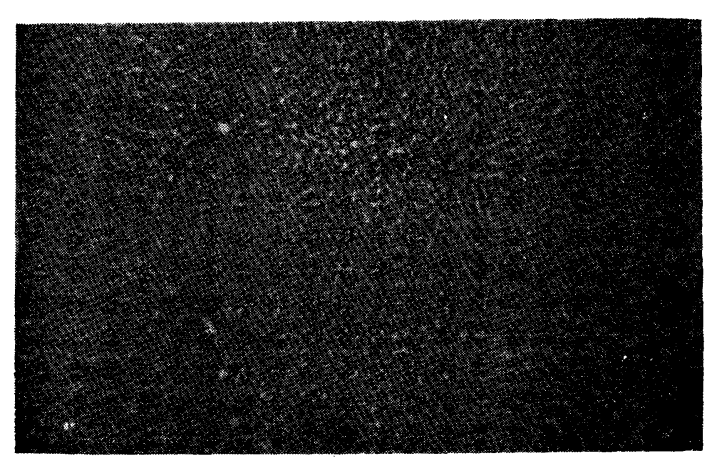

第 5 図

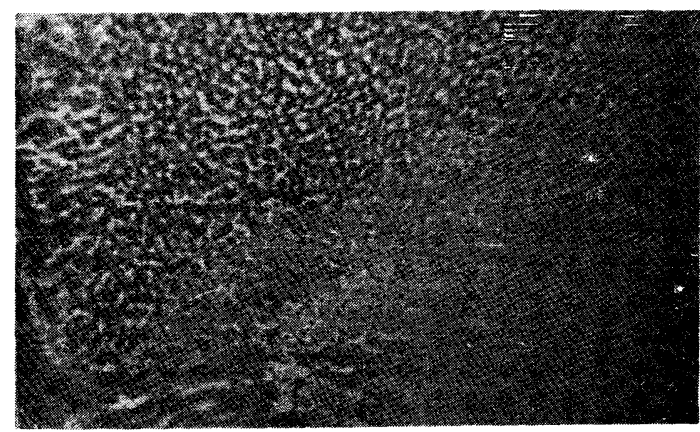

第 2 図

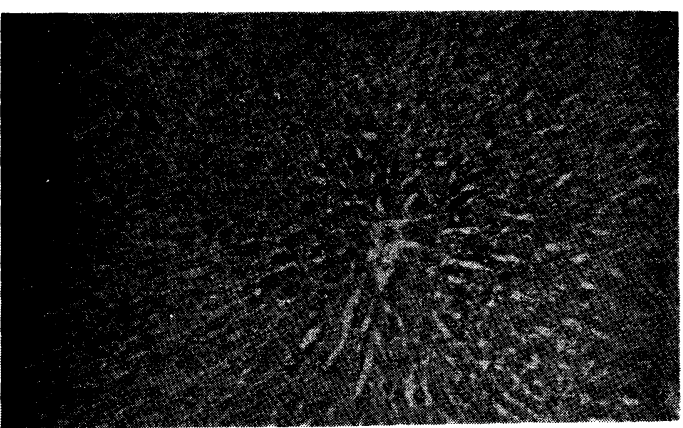

第 4 図

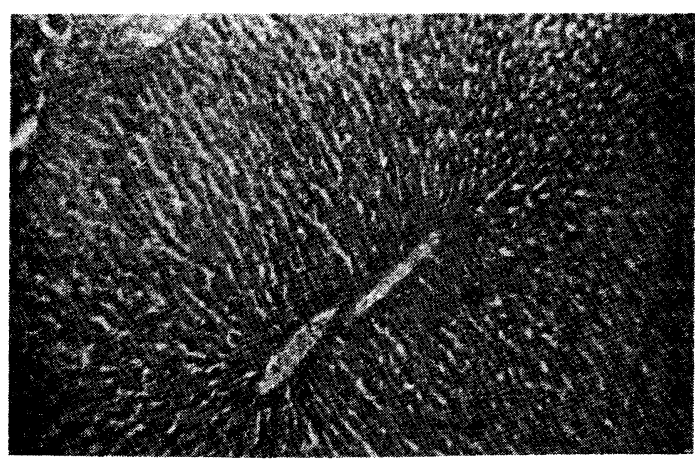

第 6 図 
吉田・横尾 $\cdot$ 上平・飯塚・石橋論文附図（其の II）

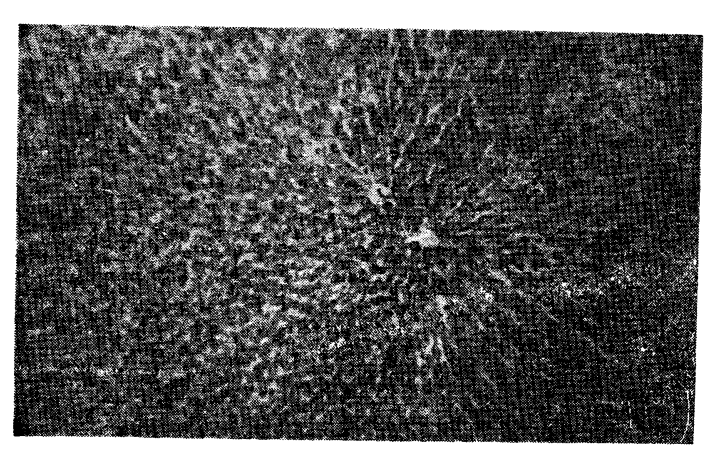

第 7 図

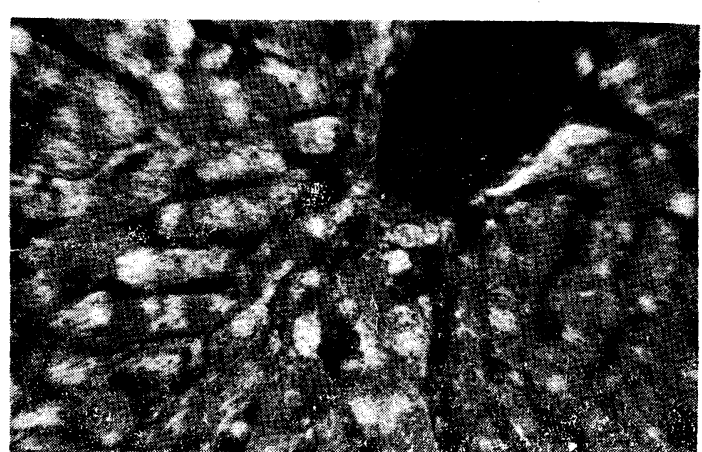

第 8 図

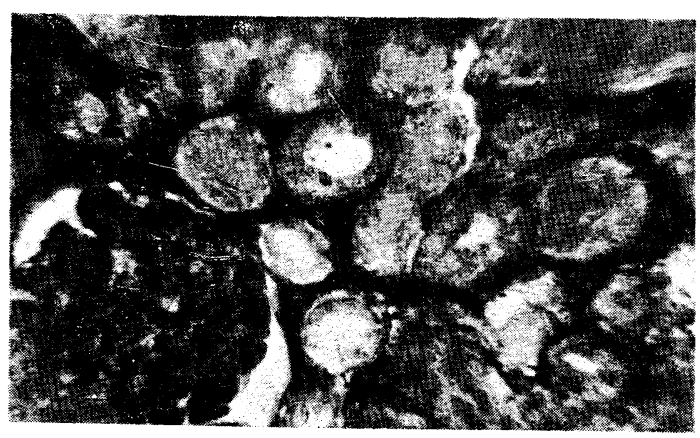

第 9 図

\section{附図説明}

第 1 図：正常家鬼の肝糖原; 肝細胞内に䨕慢性に認める. $10 \times 15$ (No. 2 ).

第 2 図：「ア」家鬼低血糖ショック時の肝糖原；小葉中心部肝細胞には允分の糖原を認む。最周讱部細胞は細 胞の膨潤，核のピクノーゼを来し糖原は全く認めず，その両者の中間㜿は糖原の減少乃至消失をみ るも，細胞には形態的変化を認めず. $10 \times 15$ (No.131).

第3 図：典型的「ア」家鬼の腎糖原；ヘンレー氏係蹄太部に扣ける糖原変性. $10 \times 40$ (No. 83) 第 4 図一第 7 図:「ス」殽 1 回投与家鬼の肝糖原.

第 4 図：投与後20分; 中心静脈周团の肝細胞のみ認む. $10 \times 15$ (No. 246).

第 5 図：投与後60分; 全肝細胞に找いて消失. $10 \times 15$ (No. 241).

第 6 図：投与後 90 分；小葉中心部肝細胞群に扣いて再び出現，回復をみる．10×15 (No.242).

第 7 図：投与後 180 分; 小葉全域の肝細胞に増加，回復をみるも，尚個々の細胞に扣いて，その含有量に差 を認む. $10 \times 15$ ( No. 220).

第 8 図：典型的「ア」家鬼の肝脂肪; 中心静脈 及び 肝細胞索間毛細血管内に脂肪血症の像を呈す。10 10 ( No. 83).

第 9 図 :「ア」家鬼二次高血糖初期の腎脂肪; 腎系毯体及び曲細尿管間毛細管内に脂肪血症の像を示す. 10× 40 (No. 78). 
iii）実験的糖尿家鬼においては心筋糖原の僅かな増加を来たす。

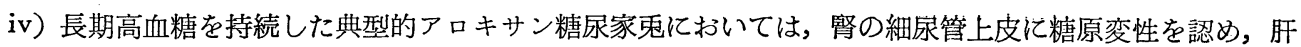
藏及び腎藏は脂肪血症の像を呈する。

3）スルファニール尿素剤投与家匝

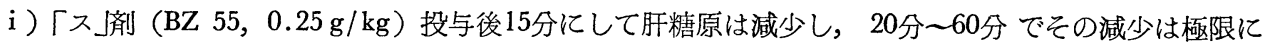
達し，為に肝糖原は全く消失する場合あある。乙の間，血糖は一時的に $25 \%$ 程度の上昇を来たす。60分を過 ぎると肝糖原は徐々に回復増加し，180 分にして略正常像に復帰する. 一方ての間血糖は一時的過血糖より 正常值に戻り更に時間の経過と共に低下を来たし，血糖降下持続時間は $2 \sim 3$ 時間に及んだ後漸次前值に復

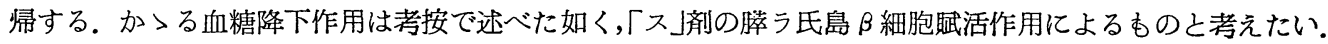

ii）「ス」棛 1 回投与群において，心糖原は投与後15分上り 180 分に亘つて稍減少する.

iii）「ス」郕旬日間連続投与，翌朝屠殺群における肝糖原は増加，正常，減少等の種々の像を呈する。

稿を終るに臨み，終始御想篤なる御指導を睗わつた本学病理学教室荒木教授に満腔の謝意を捧げる。

1) 声山, 門田 : 糖尿病の実験病理学 (岡本耕造著) 132, 137 (昭和26年).

2) Loubatieres, A. : Compt. Rend. Soc. Biol., 138, 766 (1944).

3) Tyberghein, J.M., et al. : Proc. Soc. Exp. Biol. \& Med., 92, 322 (1956).

4) Beringer, A. u. Keibl, E. : Wien. med. Wschr., 38/39, 792 (1956).

5) Miller, W.L. Jr. and Dulin, W.E. : Science, 123, 584 (1956).

6) Lang St. and Sherry, S. : Metabolism, 5(6), 733 (1956).

7) Bänder, A. u. J. Scholz : Deut. Med. Wschr., 81, 889 (1956).

8) Goldonoff und Suter : Schweiz. Med. Wschr., 86, 1409 (1956).

9) 藤本, 他 : 診療 10,8 (昭和 32年). 10) H. Yoshida et al : Folia Endocrin. Jap., Vol.34, No. 1 (1958).

11) Holt, C. et al. : Naturwissenschaften, 41, 166 (1954), 12) Holt, C. et al. : Arch. Exp. Path. \& Pharmacol., 224, 56 (1955)。13）井川，他：日本臨牃，16，41 (昭和35年). 14) 木谷: 綜合臨床, 6, 123(1957). 15）横尾：日本内分泌学会雑誌，第 34 巻，8号，758（昭33年） 講演集 (1956) 17) 大橋：日本臨床，16，32（昭和33年）. 16）三宅：日本内分泌学会東部部会 $33 ， 195$ (1957). 19) 坂井 : 神戸医大紀要, 6, 134 (昭和31年). 18）乾, 他 : 日本内分泌学会雑誌, 進歩，解剖病理篇，503 (1956)

20）伊東：基礎医学最近の 